\title{
Can Brewer-sponsored 'Drink Responsibly' Warning Message be Effective without Alcohol Policies in Nigeria?
}

\begin{abstract}
Alcohol availability, use and misuse and their related problems are rising in many parts of the African continent and this has been attributed to many factors such as non-existent or ineffective regulatory measures. In contemporary Nigeria, while a culture of intoxication is growing, there are no regulatory measures in the form of alcohol policies to reduce it. What exists is brewer-sponsored self-regulation. This paper therefore, critically analyses this selfimposed 'drink responsibly' warning message, arguing that because responsible drinking messages are strategically designed to serve the interest of alcohol industries, it cannot be effective. The paper further argues that because there are no definitions of standard drinks and where alcohol by volume (ABV) is scarcely inscribed on product labels of alcoholic beverages, such message will remain ineffective. Therefore, it recommends that an urgent step should be taken by the government to formulate and implement comprehensive evidence-based alcohol policies in Nigeria.
\end{abstract}

Keywords: Alcohol policy, alcohol-related problems, Brewer-sponsored message, Drink responsibly, Nigeria 
Nigeria is one of many countries in Africa without a coordinated response to alcohol problems. There are no policy provisions to regulate marketing and promotion of alcohol (Umoh, Obot, \& Obot, 2012 p.108).

\section{Introduction}

Nigeria has an estimated population of 173.6 million (Okpi, 2013) and this is dominated by young people who are mostly less than 26 years (Umoh et al., 2012). In Nigeria, cultural diversity, to a large extent, determines what constitute food and drinks among the ethnic groups. For example, while traditional alcoholic beverages such as pito and burukutu (fermented from Sorghum or maize) are popularly consumed in northern Nigeria, palm wine (sap from palm tree) is widely drunk in the south (Obot, 2000).

In the 1970s, the Nigerian economy experienced windfall following the rise in crude oil price in the global market (crude oil is Nigerian main export). Before this period, Nigeria had only two major alcohol companies (Nigerian Breweries and Guinness Nigeria) established in 1949 and 1962 respectively (Heap, 1996). This economic boom gave rise to an increase in disposable income. Thus, many Nigerians, especially the middle and upper class citizens, began to spend more on leisure. And due to the stiff competition among these brewers which led to increased marketing and advertising to gain brand followership (Van Den Bersselaar, 2011), there was a shift in consumption from locally-produced to industryproduced beverages (Anumonye, Omoniwa, \& Adaranijo, 1977).

Additionally, this economic growth, and the fact that state governors prioritised the establishment of alcohol companies during this period, (Alos, 2000) led to increase in production, availability and consumption of alcohol in Nigeria. Though many of these breweries became bankrupt in the 1980s during the economic recession, a few others such as the Nigerian Breweries and Guinness Nigeria survived and subsequently expanded by acquiring some of the bankrupt breweries (Alos, 2000). Some of the factors that made the Nigerian Brewery survive was that it had fortified different strategies "to grow the beer 
habit through a basic brand, Star beer, and then move up-market where it can extract more value, while defending traditional markets from penetration" (Alos, 2000 p.16).

Similarly, Guinness Nigeria has for a long time commanded large followership and through aggressive adverts, it has made many Nigerians believe that Guinness stout enhances vitality, serves as a 'Viagra' (Obot \& Ibanga, 2002) or aphrodisiac and medicine for women during their menstrual cycle (Mamman, Brieger, \& Oshiname, 2002). Another factor was that due to government reliance on alcohol tax (Alos, 2000), alcohol production and marketing were unregulated in Nigeria via policies, thus leading to the adoption of selfregulation by alcohol industries.

In the same vein, the deregulation of the Nigerian economy and introduction of neoliberal policies in 1986 (Hathaway, 1997) when the World Bank's policy of Structural Adjustment (during the recession) was adopted, facilitated the increase in private participation in the economy, and this led to the establishment of many more breweries in the late 1980 and 1990s. This deregulation facilitated the penetration of many other transnational alcohol producers into the Nigerian market in the 2000s (Jernigan \& Obot, 2006). These new alcohol companies came into Nigeria to recoup the profit margin lost in their home countries (due to stringent measures they face in those countries) (Dumbili, 2013) but this has increased alcohol marketing, promotion and availability, leading to growing alcohol-related problems in Nigeria.

Against this backdrop, this commentary critically examines the place of selfregulatory brewers'-sponsored drink responsibly (DR) warning message in Nigeria. The thrust of this paper is of two folds. Firstly, it argues that globally, it has become difficult to ignore the fact that responsible messages such as DR are meant to serve the "social responsibility" interests of the alcohol industry, and this makes it essentially ineffective (Smith, Atkin, \& Roznowski, 2006). Additionally, the paper draws on available evidence to justify the need for the formulation and implementation of comprehensive alcohol control policies in Nigeria, arguing that because DR is part of an educational/persuasive approach, it cannot reduce the growing alcohol-related problems in Nigeria. The rest of the paper is divided into three sections. While the ensuing section briefly highlights the role of the International Centre for Alcohol Policy (ICAP) on responsible drinking campaign in Nigeria, 
the section following it reveals the main reason why responsible drinking messages are ineffective. The concluding section then summarises the necessity for the formulation and implementation of alcohol control policies in contemporary Nigeria.

\section{ICAP and the politics of Responsible Drinking in Nigeria}

In many developing countries there is a growing culture of intoxication, attributable in part to factors such as alcohol marketing, pricing and increased availability (Caetano \& Laranjeira, 2006). One factor that facilitates this increase in availability according to Farrell \& Gordon (2012) is due to expansion of multinational alcohol industries to these nations. In Nigeria, in spite of what seems as relatively high abstention from alcohol consumption (World Health Organization, 2011), hazardous consumption exists among drinkers, and this is resulting in many alcohol-related problems. Early epidemiological studies revealed these problems to include: alcohol dependence (Anumonye et al., 1977), chronic illnesses (Demehin, 1984), psychological disorders (Isichei, Ikwuagwu, \& Egbuta, 1994), and mental disorder (Obot, 1990). Other problems identified recently include violence against spouses (Brisibe, Ordinioha, \& Dienye, 2012), hypertension (Dimah \& Gire, 2004), underage drinking, anxiety among students, (Adewuya, 2005; Adewuya, Ola, \& Aloba, 2006) and fatalities due to drunk driving (Ogazi \& Edison, 2012).

In consequence, one might expect concerted efforts from the government to check these problems that are threatening public health, but the reverse is the case in Nigeria. From the colonial era to date, no serious attempt has been made to reduce alcohol availability and consumption in Nigeria (Obot, 2007). Presently, what exists by way of regulation is the brewer-sponsored drink responsibly (DR) message and campaign (Dumbili, 2013). In the media, the two-word message often hurriedly ends electronic adverts after alcohol consumption has been glamourized while it is inconspicuously placed on billboards (Dumbili, 2013). Additionally, the campaign which is mainly targeted at drivers and road transport workers (Vanguard, 2011), is championed by the ICAP, in collaboration with the two major alcohol companies in Nigeria and some other organisations (they use in facilitating the campaign) such as the Federal Road Safety Commission (FRSC), the National 
Union of Road Transport Workers (NURTW) and some Non-Governmental Organizations (NGOs) (ICAP, 2013).

According to Anderson (2002), one of the major tactics ICAP uses is to create "social aspects organizations in emerging markets and low income countries" (p.1) in order to protect the interests of alcohol industries (Anderson, 2004), and this arguably is what ICAP has succeeded in doing in Nigeria. A cursory look at ICAP's activities in Nigeria since it launched its first 'drink responsibly' campaign in collaboration with Guinness in 2010 (Vanguard, 2011), reveals that, through its agency- Global Actions on Harmful Drinking (GAHD) and other NGOs, it organises and sponsors workshops and seminars in different Nigerian cities. For example, in 2011, ICAP launched a road safety event with members of the FRSC, the Advertising Practitioners Council of Nigeria, law enforcement agencies, transportation agencies and health communities in attendance (ICAP, 2011)

In all these and other ICAP-sponsored workshops and seminars, their emphasis is merely on educating members of the FRSC, tanker drivers and members of invited NGOs on issues relating to drunk driving and road safety. It has been revealed that "education strategies such as this have shown little or no effect, regardless of the investment" (Babor et al., 2010), and since ICAP's roles has remained educational in Nigeria (as in other countries), such campaigns are the lamb "lying with the lion" (Hawks, 1992 p.51), and will not command any great effect on solving alcohol-related problems in Nigeria.

Again, one unique feature of these workshops is the employment of university professors and lecturers as resource persons, and this is in accordance with what Anderson $(2002$, p.2) revealed that ICAP, in the bid to win debates surrounding alcohol policy in favour of alcohol industries, often recruits "scientists", host conferences and promotes "high profile publications". The use of these scientists as well as other governmental and NGOs authenticates McCreanor et al's (2002) argument that "the benefits to ICAP's partnership with the public have been made clear- respectability, credibility and the legitimation of ICAP's representation of industry interests in policy arenas" (p.183). Since ICAP and its allies commenced the campaign and the organization of seminars and workshops, no policy has been formulated and none are in the pipeline. Meanwhile alcohol marketing, availability and alcohol-related problems have been increasing in Nigeria. 


\section{The Ineffectiveness of 'Drink Responsibly' as a warning Message}

As noted, DR warning message is the only available message in Nigeria but the message is fraught with many weaknesses that will be revealed in this discourse. Essentially, evidence from different parts of the globe suggests that the prevalence of alcohol-related problems can only be reduced if overall consumption is reduced, and that such a reduction in consumption can only be achieved by stringent regulatory measures aimed at increasing the price and decreasing availability (Anderson, Chisholm, \& Fuhr, 2009; Babor et al., 2010; Stockwell, Auld, Zhao, \& Martin, 2012).

In different parts of the world, evidence shows that alcohol industries often oppose any movement that can engender the formulation of stringent policies that may reduce alcohol production and availability (Anderson, 2009; Babor et al., 2010). They prefer to employ responsible drinking messages as part of their social responsibility tools (Pantani, Sparks, Sanchez, \& Pinsky, 2012), but this has been proved to serve as public relation tools which "may hope to head off further regulation efforts... gain credibility as good citizens who want what is best for society" (Wolburg, 2005 p.176). One of the reasons DR is a selfserving tool according to Smith et al. (2006 p.1) is that it is strategically designed to "create a positive image if the target audience perceives it as socially responsible" and this according to Atkin, McCardle, \& Newell (2008) improves the company's overall reputation. For example, Barry \& Goodson (2010) note that 91\% in a survey of "956 Americans", perceive the message as "a good thing" and this is because such messages are strategically loaded with ambiguity, which makes "individuals evaluate both the messages' content and the company's overall image positively" (p.297). In relation to this, alcohol industries often argue that moderate alcohol consumption is not harmful to human health (Casswell, 2013), but the definition of moderation is often problematic (Barry \& Goodson, 2010).

In Nigeria, it can be argued that the use of such messages and tactics to improve company's reputation is what brewers are doing. Following the adoption of the 10-point policy resolution by the World Health Assembly in 2010 (Chick, 2011), the two main sponsors of this DR message in Nigeria, initiated their 'drink responsibly campaigns' with other strategic social responsibilities initiated in 2010 (Dumbili, 2013). This arguably was to 
hinder any attempt to formulate any policy that may reduce alcohol availability (Vanguard, 2011) .

Interestingly, just as Roznowski \& Eckert (2006) note that "for every responsibility advertisement (aired on television) in 2002 in the USA, there were 226 ads", a similar thing happens in Nigeria. As the ICAP and alcohol companies are organising this campaign on one hand, the same alcohol producers on the other hand simultaneously engage in diverse aggressive marketing in order to increase sales and profits (Jernigan \& Obot, 2006). One of strategies they employ is the frequent drink-and-win promos (De Bruijn, 2011) where people are encouraged to drink and win codes or numbers (concealed under the crown cork of bottles) that can be used to redeem more free drinks, cash, cars, electricity generating sets, mobile phones and tickets to do shopping in Dubai (Agency Reporter, 2013).

As noted earlier, one reason this has persisted is government's economic interests (Ibanga et al., 2005), but this is to the detriment of public health. This is why Obot (2013) notes that "alcohol industry is a vector for health and social problems in Africa because it exists to propagate consumption of an addictive substance through unfair ways and means that subvert the rights of young people and vulnerable groups" (p.65-66).

Some other problems with responsible messages are that they ignore the objectives of public health objectives because they are designed to put the blame on the consumer (rather than the producer or supplier); for instance, if something bad happens, it means consumers have not been drinking responsibly (Roznowski \& Eckert, 2006). According to Dowling, Clark, \& Corney, 2006 (p.42), “individuals... require knowledge about responsible drinking practices so they can make informed decisions about their alcohol consumption". In Nigeria, no such source of knowledge exists. Nigeria to date does not have a definition of what constitute 'standard drinks' for adults, which are the official basis for judging responsible and irresponsible consumption (Obot, 2007), and alcoholic beverages scarcely carry $A B V$ on their labels that can guide consumers on the percentage of $A B V$ on each alcoholic beverage (Dumbili, 2013). Guinness Nigerian and the Nigerian Breweries (makers of Heineken) have recently started inscribing $A B V$ on some of their products, but this may be because they export these products to countries where this is mandatory. With the 
extant lack of proper education on how to drink in moderation, how easily can responsible drinking be known and adhered to in Nigeria? Again, Nigeria is a country with high illiteracy level and a myriad of local languages and no brewer to date has any local translation of DR (Dumbili, 2013).

Additionally, Fisher, Simpson, \& Kapur (1987) argue that "it would seem that having tables (that can help in estimating blood alcohol concentration BAC) at hand and counting drinks is the simplest way of drinking and/or serving responsibly" (Fisher et al., 1987 p.301). In Nigeria however where "drinking and driving is usually inferred from physical observation because no equipment is available to measure BAC' (Ogazi \& Edison, 2012 p.116), how can responsible drinking be understood and adhered to among drivers and general public?

Further, in the USA, irrespective of the fact that it has been argued to be ineffective, separate public service announcements (PSAs) about responsible drinking are aired on the TV (Dejong \& Atkin, 1995) "primarily through paid advertising" (DeJong, Atkin, \& Wallack, 1992 p.661). It is noteworthy that some of the reasons the PSAs may produce low results according to Babor et al. (2010), is that they are usually few in number compared to "the volume of alcohol advertisements, and are rarely seen on the television". Similarly, "their contents cannot easily change the other persuasive influences supportive of drinking" (p.200-1). Despite these flaws, Barry \& Goodson (2010) noted that many of the responsible drinking messages involve "talking ahead" which involves the use of "various celebrities and sports figures to deliver public-type messages" (p.296). In Nigeria, in contrast, none of these exist at present. There are no separate PSAs addressing alcohol misuse (Dumbili, 2013); instead, brewers are employing celebrities and sports legends to advertise and promote their products (De Bruijn, 2011; Obot \& Ibanga, 2002) as well as sponsoring different night youth-oriented programmes where admission is free, and alcohol is either served free or at subsidized prices (Thisday, 2013).

\section{Concluding Remark}

\section{The Necessity of Alcohol control Policies in Nigeria}


This paper has briefly explored the increasing alcohol-related problems in Nigeria and the inability of the ICAP and brewers-sponsored responsible drinking message and campaign to reduce them. It is noteworthy that lack of alcohol policy or alcohol industries' or their allies' interference with the policy process is not a Nigerian reserve. In many African countries such as Botswana, Malawi, Lesotho, Uganda, etc., vested interest by alcohol producing industries marred the policy process by either delaying its formulation or determining the poor content of the formulated policies (Bakke \& Endal, 2010).

Irrespective of the fact that these countries' policy processes were marred by vested interests, it is obvious that such policies can be improved upon with evidence-based research and advocacy. As noted, with the available evidence of the harm excess alcohol availability and consumption cause in Nigeria, there has been little or no serious move to formulate alcohol policies. In fact, in the 1970s, scholars such as Anumonye et al. (1977) called on the government to formulate policies that will check the rising alcohol availability and misuse in Nigeria. Thirty seven years later, no serious attempt, has been made by the government, the health practitioners, the legislatures or the NGOs that can engender the formulation of alcohol policies in Nigeria. Even the Tobacco Bill that was passed by the Nigerian House of Senate on March 15, 2011 (Agaku, Akinyele, \& Oluwafemi, 2012) has not been signed into law by the incumbent president and the reason is not unconnected with economic interests.

As it has been argued that economic interest should not always overshadow public health interest (Babor et al., 2010), Nigerian government should jettison any commercial interest and address this lack of policy in order to tackle the rising alcohol availability, harmful alcohol consumption and their related problems. A step in the right direction would be to adopt the WHO 2010, 10-point policy thrust to formulate and implement evidencebased policies that will regulate "the physical availability of alcohol by partial or total bans, regulating retail outlet, hours and days of sale" (Umoh et al., 2012 p.113). This will in turn, "protect health, prevent disability, and address the social problems associated with the misuse of beverage alcohol"' (Babor et al., 2010 p.2).

To ensure that effective evidence-based policies are formulated and implemented, brewers and ICAP must be distanced from the policy process - otherwise what happened in some African countries due to vested interests (Bakke \& Endal, 2010) may well be replicated 
in Nigeria. It has been argued that the placement of warning messages at the front of the product label, the use of coloured pictorials or posters (Fenaughty \& MacKinnon, 1993; Loeber et al., 2011) and the conspicuous arrangement of texts enhance recall ability of consumers (Andrews, 1995; Barlow \& Wogalter, 1993; Laughery, Young, Vaubel, \& Brelsford Jr, 1993) and engender behaviour change: this should be included in the policy to help mostly illiterate Nigerians.

In the meantime, (before a comprehensive policy is formulated) the DR message should be replaced with more explicit warning messages. Following the example of Canada (2000) and Brazil (2001), brewers in Nigeria should be legally encouraged to initiate rotational warning messages rather than using just one that is ineffective (Argo \& Main, 2004). People should also be encouraged to abstain from drinking because "abstinence is a socially acceptable choice" (DeJong et al., 1992 p.675).

In the same vein, alcohol promotions (e.g. buy one get one free) should be banned because it has been reported to facilitate alcohol initiation among minors (De Bruijn, 2011 p.37). Though Nigeria is the focus, there is a need to inform other countries where brewers and ICAP's collaboration exist that such collaboration is often aimed at winning "the war of ideas that shape alcohol policy" (to favour alcohol industries) (McCreanor et al., 2002 p.179). Therefore, such collaboration should be discouraged because it will either delay policy formulation (where policy does not exist), or encourage the formulation of ineffective policies that may adversely affect public health. 


\section{References}

Adewuya, A. O. (2005). Validation of the alcohol use disorders identification test (audit) as a screening tool for alcohol-related problems among Nigerian university students. Alcohol and Alcoholism, 40(6), 575-577.

Adewuya, A. O., Ola, B. A., \& Aloba, O. O. (2006). Gender differences in the relationship between alcohol use and anxiety symptoms among Nigerian college students. Drug and Alcohol Dependence, 85(3), 255-257.

Agaku, I., Akinyele, A., \& Oluwafemi, A. (2012). Tobacco control in Nigeria-policy recommendations. Tobacco Induced Diseases, 10(1), 1-4.

Agency Reporter. (2013). First Dubai-bound legend promo winners emerge today. Retrieved 10 August, 2013, from http://www.punchng.com/entertainment/arts-life/first-dubaibound-legend-promo-winners-emerge-today/

Alos, A. J. (2000). Creating value under uncertainty: The Nigerian experience. Journal of African Business, 1(1), 9-24.

Anderson,

P.

(2002).

The beverage alcohol Industry's social aspects organizations: A public health warning. London: Global Alcohol Policy Alliance.

Anderson, P. (2009). Global alcohol policy and the alcohol industry. Current Opinion in Psychiatry, 22(3), 253-257.

Anderson, P., Chisholm, D., \& Fuhr, D. C. (2009). Effectiveness and cost-effectiveness of policies and programmes to reduce the harm caused by alcohol. The Lancet, 373(9682), 2234-2246.

Anderson, P. (2004). The beverage alcohol industry's social aspects organizations: A public health warning. Addiction, 99(11), 1376-1377.

Andrews, J. C. (1995). The effectiveness of alcohol warning labels: A review and extension. American Behavioral Scientist, 38(4), 622-632.

Anumonye, A., Omoniwa, N., \& Adaranijo, H. (1977). Excessive alcohol use and related problems in Nigeria. Drug and Alcohol Dependence, 2(1), 23-30. 
Argo, J. J., \& Main, K. J. (2004). Meta-analyses of the effectiveness of warning labels. Journal of Public Policy \& Marketing, 23(2), 193-208.

Atkin, J., McCardle, M., \& Newell, S. (2008). The role of advertiser motives in consumer evaluations of 'responsibility 'messages from the alcohol industry. Journal of Marketing Communications, 14(4), 315-335.

Babor, T., Caetano, R., Casswell, S., Edwards, G., Giesbrecht, N., Graham, K., Rossow, I. (2010). Alcohol: No ordinary commodity: Research and public policy (Second Ed.). New York: Oxford Univ Press.

Bakke, Ø., \& Endal, D. (2010). Vested interests in addiction research and policy alcohol policies out of context: Drinks industry supplanting government role in alcohol policies in sub-Saharan Africa. Addiction, 105(1), 22-28.

Barlow, T., \& Wogalter, M. S. (1993). Alcoholic beverage warnings in magazine and television advertisements. Journal of Consumer Research, 20(1), 147-156.

Barry, A. E., \& Goodson, P. (2010). Use (and misuse) of the responsible drinking message in public health and alcohol advertising: A review. Health Education \& Behavior, 37(2), 288-303.

Brisibe, S., Ordinioha, B., \& Dienye, P. O. (2012). Intersection between alcohol abuse and intimate Partner's violence in a rural ijaw community in Bayelsa state, south-south nigeria. Journal of Interpersonal Violence, 27(3), 513-522.

Caetano, R., \& Laranjeira, R. (2006). A 'perfect storm' in developing countries: Economic growth and the alcohol industry. Addiction, 101(2), 149-152.

Casswell, S. (2008). Alcohol industry and alcohol policy-the challenge ahead. Addiction, 104(s1), 3-5.

Casswell, S. (2013). Vested interests in addiction research and policy. why do we not see the corporate interests of the alcohol industry as clearly as we see those of the tobacco industry? Addiction, 108(4), 680-685.

Chick, J. (2011). The WHO global strategy to reduce the harmful use of alcohol. Alcohol and Alcoholism, 46(3), 223-223.

De Bruijn, A. (2011). Alcohol marketing practices in Africa- findings from Gambia, Ghana, Nigeria and Uganda. Utrecht (the Netherlands): Dutch Institute of Alcohol Policy (STAP). 
Dejong, W., \& Atkin, C. K. (1995). A review of national television PSA campaigns for preventing alcohol-impaired driving, 1987-1992. Journal of Public Health Policy, 16(1), $59-80$.

DeJong, W., Atkin, C. K., \& Wallack, L. (1992). A critical analysis of" moderation" advertising sponsored by the beer industry: Are" responsible drinking" commercials done responsibly? The Milbank Quarterly, 70(4), 661-678.

Demehin, A. (1984). Drug abuse and its social impacts in Nigeria. Public Health, 98(2), 109116.

Dimah, A., \& Gire, J. T. (2004). The health and economic consequences of alcohol use in central Nigeria. African Journal of Drugs and Alcohol Studies, 3(1\&2), 44-53.

Dowling, N., Clark, D., \& Corney, T. (2006). Responsible drinking knowledge: A comparison of Australian apprentices and university students. Youth Studies Australia, 25(3), 42-48.

Dumbili, E. (2013). The politics of alcohol policy in Nigeria: A critical analysis of how and why brewers use strategic ambiguity to supplant policy initiatives. Journal of Asian and African Studies, 1-15. Doi: 10.1177/0021909613490137.

Farrell, T., \& Gordon, R. (2012). Critical social marketing: Investigating alcohol marketing in the developing world. Journal of Social Marketing, 2(2), 138-156.

Fenaughty, A. M., \& MacKinnon, D. P. (1993). Immediate effects of the Arizona alcohol warning poster. Journal of Public Policy \& Marketing, 12(1), 69-77.

Fisher, H. R., Simpson, R. I., \& Kapur, B. M. (1987). Calculation of blood alcohol concentration (BAC) by sex, weight, number of drinks and time. Canadian Journal of Public Health, 78(5), 300-304.

Hathaway, J. T. (1997). Women and The Public Drinking Place: A Case Study Of Ado-Ekiti, Nigeria. Singapore Journal of Tropical Geography, 17(2), 132-149.

Hawks, D. (1992). Lying down with the lion: Co-operating with the alcohol industry? The 1991 Leonard ball oration. Drug and Alcohol Review, 11(1), 51-58.

Heap, S. (1996). Before" Star": The import substitution of western-style alcohol in Nigeria, 1870-1970. African Economic History, 24, 69-89.

Ibanga, A., Adetula, A., Dagona, Z., Karick, H., Ojiji, O., Obot, I., \& Room, R. (2005). The contexts of alcohol consumption in Nigeria. Alcohol, Gender and Drinking Problems: 
Perspectives from Low and Middle Income Countries, 143-166. Geneva: World Health Organization.

ICAP. (2011b). Global actions Nigeria to launch landmark road safety event in Abuja. $\begin{array}{llll}\text { Retrieved January 23, 2014, from } & \text { 23 }\end{array}$ http://www.icap.org/LinkClick.aspx?fileticket=3bvGXIW1uD4\%3D\&tabid=71

ICAP. (2013). ICAP holds drink driving capacity Building Workshop in Abuja, Nigeria. $\begin{array}{llll}\text { Retrieved January 23, 2014, from } & \text { 23 }\end{array}$ http://www.icap.org/LinkClick.aspx?fileticket=q7aDftDMruU\%3D\&tabid=36

Isichei, H., Ikwuagwu, P. U., \& Egbuta, J. (1994). A comparative study of alcoholic patients in Jos, Nigeria, and in Castrop-Rauxel, Germany. Alcohol and Alcoholism, 29(1), 75-78.

Jernigan, D. H., \& Obot, I. S. (2006). Thirsting for the African market. African Journal of Drug and Alcohol Studies, 5(1), 57-70.

Laughery, K. R., Young, S. L., Vaubel, K. P., \& Brelsford Jr, J. W. (1993). The noticeability of warnings on alcoholic beverage containers. Journal of Public Policy \& Marketing, 12(1), 38-56.

Loeber, S., Vollstadt-Klein, S., Wilden, S., Schneider, S., Rockenbach, C., Dinter, C., Winterer, G. (2011). The effect of pictorial warnings on cigarette packages on attentional bias of smokers. Pharmacology Biochemistry and Behavior, 98(2), 292-298.

Mamman, L. S., Brieger, W. R., \& Oshiname, F. O. (2002). Alcohol consumption pattern among women in a rural Yoruba community in Nigeria. Substance use \& Misuse, 37(57), 579-597.

McCreanor, T., Casswell, S., \& Hill, L. (2002). ICAP and the perils of partnership. Addiction, 95(2), 179-185.

Obot, I., \& Ibanga, A. (2002). Selling booze: Alcohol marketing in Nigeria. The Globe, 2, 6-10.

Obot, I. S. (1990). Substance abuse, health and social welfare in Africa: An analysis of the Nigerian experience. Social Science \& Medicine, 31(6), 699-704.

Obot, I. S. (2000). The measurement of drinking patterns and alcohol problems in Nigeria. Journal of Substance Abuse, 12(1-2), 169-181.

Obot, I. S. (2007). Nigeria: Alcohol and society today. Addiction, 102(4), 519-522.

Obot, I. (2013). Alcohol marketing in Africa: Not an ordinary business. African Journal of Drug and Alcohol Studies, 12(1), 63-73. 
Ogazi, C., \& Edison, E. (2012). The drink driving situation in Nigeria. Traffic Injury Prevention, 13(2), 115-119.

Okpi, A. (2013, November 17). Nigeria's population to exceed 440 million in 2050. Punch Online News. Retrieved 10 August, 2013 from http://www.punchng.com/news/nigerias-population-to-exceed-440-million-in-2050/.

Pantani, D., Sparks, R., Sanchez, Z. M., \& Pinsky, I. (2012). 'Responsible drinking 'programs and the alcohol industry in brazil: Killing two birds with one stone? Social Science \& Medicine, 75(8) 1387-1391.

Roznowski, J. L., \& Eckert, J. A. (2006). Exploring what "Drink responsibly" means to college students. Journal of Current Issues \& Research in Advertising, 28(1), 19-30.

Smith, S. W., Atkin, C. K., \& Roznowski, J. A. (2006). Are "drink responsibly" alcohol campaigns strategically ambiguous? Health Communication, 20(1), 1-11.

Stockwell, T., Auld, M. C., Zhao, J., \& Martin, G. (2012). Does minimum pricing reduce alcohol consumption? the experience of a Canadian province. Addiction, 107(5), 912920.

Thisday Newspaper. (2013). How legend used promo to boost consumers' experience. Retrieved 10 August, 2013, from http://www.thisdaylive.com/articles/how-legendused-promo-to-boost-consumers-experience/148779/

Umoh, O. O., Obot, P. P., \& Obot, I. (2012). Perception of alcohol availability, promotion and policy by Nigerian university students. African Journal of Drug Alcohol Studies, 11(2), 107-116.

Van Den Bersselaar, D. (2011). Who belongs to the 'Star People'? Negotiating Beer and Gin Advertisements in West Africa, 1949-75. The Journal of African History, 52(03), 385408.

Vanguard Newspaper (2011, October 21). Guinness Nigeria champions 'drink responsibly' $\begin{array}{llll}\text { campaign. } & \text { Retrieved } & 10 & \text { August, }\end{array}$ http://www.vanguardngr.com/2011/10/guinness-nigeria-champions-'drinkresponsibly\%E2\%80\%99-campaign/

Wolburg, J. M. (2005). How responsible are "responsible" drinking campaigns for preventing alcohol abuse? Journal of Consumer Marketing, 22(4), 176-177.

World Health Organization. (2011). Global status report on alcohol and health. Geneva: World Health Organization. 
